\title{
Amos Goldberg
}

\section{Czy w Nowym Muzeum Historii Zagłady Yad Vashem znajdziemy „Innego”?}

\begin{abstract}
„[T]o właśnie «ostateczne rozwiązanie» pozwala postmodernistom kwestionować prawomocność wszelkiego totalizującego postrzegania historii, wszelkich odniesień do dającego się zdefiniować metadyskursu, dopuszczając w ten sposób wiele równoprawnych podejść" 1 .
\end{abstract}

Saul Friedländer

„Trzeba by kiedyś, powiedział jeszcze, sporządzić katalog naszych konstrukcji, uporządkowanych według wielkości, a zaraz stałoby się jasne, że budowle sytuujące się poniżej normalnej miary architektury domowej - szałasy, pustelnie, budki strażników śluz, pawilony widokowe, ogrodowe domki dla dzieci - tchną przynajmniej jakimś odblaskiem pokojowego życia, natomiast nikt przy zdrowych zmysłach nie byłby gotów powiedzieć, że podoba mu się taki kolos jak choćby brukselski Pałac Sprawiedliwości na dawnym wzgórzu szubienicznym. W najlepszym wypadku można go podziwiać, a ten podziw jest wstępną formą zgrozy, bo jakoś tam wiemy przecież, że rozrosłe ponad miarę budowle rzucają już cień własnej destrukcji i zaprojektowane są od początku pod kątem przyszłego bytowania w charakterze ruin”.

Winfried G. Sebald, Austerlitz $z^{2}$

\section{Muzeum w kontekście}

Jak zasugerowali Daniel Levy i Natan Sznaider, a w innym ujęciu również Jeffrey Alexander i wielu innych badaczy³, pamięć o Zagładzie stała się paradygmatem nowej formy pamięci zbiorowej, której nadali miano pamięci globalnej (global

\footnotetext{
${ }^{1}$ Saul Friedländer, Introduction [w:] Probing the Limits of Representation, red. Saul Friedländer, s. 5.

${ }^{2}$ Winfried G. Sebald, Austerlitz, tłum. Małgorzata Łukasiewicz, Warszawa: W.A.B., s. $24-25$.

${ }^{3}$ Daniel Levy, Natan Sznaider, The Holocaust and Memory in the Global Age, tłum. Assenka Oksiloff, Philadelphia: Temple University Press, 2006; Jeffrey C. Alexander, On the Social Construction of Moral Universals: The „Holocaust” from Mass Murder to Trauma Drama [w:] Mass Murder to Trauma Drama, „European Journal of Social Theory” 2002, t. 5, nr 1, s. 5-86. Zob. też: Tony Judt, Powojnie. Historia Europy od roku 1945, tłum. Robert Bartołd, Poznań: Rebis, 2008; Universalisierung des Holocaust? Erinnerungskultur und Gesschictspolitik in internationaler perspective, t. 24, red. Jan Eckel, Claudia Moisel, Göttingen: Wallstein, 2008.
} 
memory). Owa nowa forma nie jest, jak niegdyś, powiązana z koherentną grupą polityczną lub społeczną, taką jak „naród” czy „grupa etniczna”, lecz przede wszystkim z bardziej globalnym, acz niedookreślonym bytem zbiorowym, czyli z „Zachodem”. Ta nowa pamięć globalna o Zagładzie jest środkiem do tworzenia bardzo szerokiej „wspólnoty wyobrażonej” i kładzie podwaliny pod to, co Levy i Sznaider nazywają nową etyką kosmopolityczną. Inni podchodzą do owej „etyki kosmopolitycznej” ze znacznie większym sceptycyzmem, trudno jednak zaprzeczyć, że w wielu rejonach świata pamięć o Zagładzie i dyskurs holokaustowy są bardzo szeroko rozpowszechnione, a ją samą uznaje się za ważne symboliczne wydarzenie historyczne i etyczne. Niektórzy historycy, który dostrzegli tę zmianę, sugerują nawet, że Zagłada zajęła obecnie miejsce rewolucji francuskiej jako mitu założycielskiego Zachodu - mitu nadającego ogólny sens etyczny i polityczny naszej epoce ${ }^{4}$.

Sugerowałbym, że ta zmiana pamięci o Zagładzie, jak również zmiana znaczenia „pamięci zbiorowej” znajduje swoje odzwierciedlenie w zmianach, jakie zaszły ostatnio w Yad Vashem - izraelskim Instytucie Pamięci Męczenników i Bohaterów Holokaustu.

Yad Vashem założono w 1953 r. na mocy ustawy przyjętej przez Państwo Izrael (choć historia założenia instytutu sięga lat czterdziestych) ${ }^{5}$. Dawała ona instytutowi prawo do ustanowienia miejsca pamięci, zbierania, badania i publikowania relacji o Zagładzie, uczenia o niej i odznaczania Sprawiedliwych wśród Narodów Świata, czyli tych osób, które ratowały Żydów. Początkowo była to niewielka instytucja, rywalizująca z innymi narodowymi miejscami pamięci, takimi jak piwnica Muzeum Holokaustu na górze Syjon ${ }^{6}$ czy te zlokalizowane na terenie kibuców Yad Mordechai i Lohamei Hageta’ot.

Stopniowo kompleks Yad Vashem stał się głównym izraelskim miejscem pamięci o Zagładzie, a także jednym z najważniejszych miejsc-symboli w kraju. Pierwszą ekspozycję historyczną o podstawowym znaczeniu zaprezentowano w Yad Vashem na początku lat sześćdziesiątych. W 1973 r. otwarto stałą, wyczerpującą i uporządkowaną chronologicznie wystawę historyczną, którą później uaktualniano i zmieniano.

${ }^{4}$ Zob. na przykład: Lothar Probst, Founding Myths in Europe and the Role of the Holocaust, „New German Critique” 2003, nr 90, s. 45-48; Alon Confino, The Holocaust as a Symbolic Manual: The French Revolution, the Holocaust, and Global Memories (w przygotowaniu).

${ }^{5}$ Więcej o wczesnej historii Yad Vashem zob. Roni Stauber, The Holocaust in Israeli Public Debate in the 1950s: Ideology and Memory, London: Vallentine Mitchell 2007; Muli Brug, The Memorialization of the Holocaust [w:] Tom Segev, The Seventh Million: The Israelis and the Holocaust, tłum. Haim Watzman, New York: Henry Holt \& Co., 1993; Boaz Cohen, Israeli Holocaust Research: Birth and Evolution, London: Routledge 2011; James Young, The Texture of Memory, New Haven: Yale University Press, 1993; Ajala Plezental, Cricha ha-hanhala lehargisz... ki jesz kan ma'awak [Przywódcy muszą zrozumieć, że toczy się tu walka], praca magisterska, Uniwersytet Hebrajski w Jerozolimie; Jochaj Cohen, „Mot Giborim”. Chajaw u-moto szel mitos ha-gwura be-Yad wa-Szem 1942-2005 [Śmierć bohaterów. Życie i śmierć heroicznego mitu w Yad Vashem 1942-2005], praca magisterska, Jerozolima 2009.

${ }^{6}$ Doron Bar, Holocaust Commemoration in Israel during the 1950s: The Holocaust Cellar in Mount Zion, „Jewish Social Studies”, jesień 2005, t. 12, nr 1, s. 16-38. 
Wraz ze wzrostem światowego zainteresowania Zagładą pod koniec lat osiemdziesiątych i dziewięćdziesiątych XX w. do Yad Vashem zaczęli chętnie przybywać goście z Izraela i z zagranicy w celach edukacyjnych, ale też turystycznych. O ile wiem, już w latach dziewięćdziesiątych było to drugie po Ścianie Płaczu najczęściej odwiedzane przez turystów miejsce w kraju.

W ciągu ostatnich dwudziestu lat Yad Vashem stało się ogromną instytucją, zatrudniającą w swych wydziałach setki pracowników, nauczycieli i badaczy. Instytut współpracuje z wieloma wpływowymi instytucjami politycznymi i kulturalnymi z innych krajów, a odwiedzają go miliony ludzi z całego świata. Tak więc nie tracąc swojego lokalnego i narodowego (uświęconego) znaczenia, Yad Vashem zmieniło się $\mathrm{w}$ powszechnie znane miejsce pamięci, tłumnie odwiedzane przez gości z całego świata? ${ }^{7}$ Stało się ono - wraz z Muzeum Pamięci Holokaustu w Waszyngtonie, Pomnikiem Pomordowanych Żydów Europy w Berlinie i Muzeum Auschwitz-Birkenau - międzynarodową „świątynią” pamięci o Zagładzie, jak również celem pielgrzymek. Te cztery „świątynie” są punktem oparcia dla nowej pamięci etycznej o Zagładzie, która stanowi podstawowy element obecnej tożsamości Zachodu. Wyznaczają one też niejako geokulturową mapę „świadomości Zagłady”, obejmującą Europę Zachodnią i Wschodnią, Amerykę Północną oraz Izrael.

Yad Vashem przekształcił się zatem z izraelskiego, lokalnego lieux de memoir (miejsca pamięci), by użyć znanego terminu Pierre’a Nory, w potężną i wpływową instytucję kulturalną o międzynarodowym znaczeniu.

Ze względu na te zmiany, a zwłaszcza po otwarciu w 1993 r. imponującego waszyngtońskiego Muzeum Pamięci Holokaustu uznano, że muzeum historyczne należy przekształcić. Tak więc w wyniku opisanych wcześniej procesów w 2005 r. miejsce skromnej wystawy, składającej się głównie ze zdjęć, zajęło bardzo nowoczesne i oryginalnie skonstruowane muzeum, co stało się możliwe dzięki powiększeniu i przebudowie całego kompleksu Yad Vashem.

W tym krótkim eseju muzeum Yad Vashem stanie się przedmiotem mojej krytycznej oceny ${ }^{8}$. Dokonam jej w kontekście wspomnianego już procesu globalizacji pamięci o Zagładzie.

Najpierw jednak chciałbym poczynić dwa bardzo ważne zastrzeżenia. Pierwsze odnosi się do charakteru mojej analizy. W eseju tym postaram się zasugerować

\footnotetext{
${ }^{7}$ Relacje między tym, co globalne, a tym, co lokalne, są zawsze bardzo złożone. Dlatego też socjologowie wprowadzili termin „glokalizacja”, trafniej opisujący te procesy. Zob. na przykład Roland Robertson, Glocalization: Time-Space and Homogeneity-Heterogeneity [w:] Global Modernities, red. Mike Fearherstone, Scott Lash, Roland Robertson, London: Sage, 1995, s. 25-44.

${ }^{8}$ Więcej na temat nowego muzeum Yad Vashem zob.: Eran Neuman, Nofej Szoa monumentalim be-Jad wa-Szem [Monumentalne obrazy Zagłady w Yad Vashem], „Dapim” 2007, nr 21, s. 35-54; idem, The Plan as a Text: Masochistic Architecture at Yad Vashem, „Theory and Criticise", wiosna 2006, nr 28, s. 249-258. Więcej na temat funkcji muzeum we współczesnym życiu zob. Museums and Memory, red. Susan A. Crane, Stanford: Stanford University Press, 2000.
} 
interpretację wystawy muzealnej jako formy narracji. Zbadam, jaki rodzaj opowieści historycznej prezentuje oraz przeanalizuję jej wady. Zdaję sobie sprawę, że taka analiza jest bardzo stronnicza. Wszak muzeum to nie podręcznik historii i nie ma w nim miejsca na zaprezentowanie wszystkich jej zawiłości. Co więcej, nie jest ono jedynie tekstem, lecz czymś znacznie więcej. Muzealna prezentacja oraz doświadczenia zwiedzających wchodzą ze sobą w wieloaspektowe relacje. Na przykład wykładowcy lub przewodnicy „przedstawiają” muzeum zwiedzającym, kontekstualizując różnorakie eksponaty oraz włączając do swych wypowiedzi wiele informacji, których nie zamieszczono na planszach. Niniejszy esej pomija kwestię tego zjawiska oraz innych znaczących czynników składających się na odbiór muzeum u zwiedzających'.

Drugie zastrzeżenie odnosi się do zakresu mojej analizy krytycznej. Skupię się tutaj jedynie na muzeum, a nie na Yad Vashem jako miejscu pamięci lub instytucji oświatowej i badawczej składającej się z różnych działów. W skład ośrodka wchodzą między innymi: doskonale zaopatrzona biblioteka, jedno z największych archiwów cyfrowych dotyczących Zagłady, Międzynarodowa Szkoła Nauczania o Holokauście, do której przybywają dziesiątki tysięcy nauczycieli i uczniów z Izraela oraz z zagranicy na organizowane tam krótkie lub długie serie seminariów o Zagładzie, bardzo prestiżowy akademicki ośrodek naukowy, którego liczne struktury skupiają najwybitniejszych badaczy Zagłady z całego świata i który inicjuje oraz wspiera jedne z najbardziej przełomowych badań nad Szoa, świetne i ważne wydawnictwo publikujące opracowania na temat Zagłady oraz relacje (spośród jego doskonałych publikacji na szczególną uwagę zasługuje znakomite pismo „Yad Vashem Studies”). Wszystkich tych kwestii nie uwzględniam w mojej analizie, należy ją zatem uznać za zawężoną ${ }^{10}$.

Mimo to uważam, że analiza narracji prezentowanej przez muzeum może wiele wyjaśnić i okazać się pomocna. Esej ten jest więc przede wszystkim wezwaniem do dyskusji i debaty - zjawisk stanowiących podstawę naszej kultury akademickiej i nieodzownych dla istnienia żywej sfery publicznej, w której można się zastanawiać nad charakterem naszej pamięci i tożsamości.

\footnotetext{
${ }^{9}$ Antropolog Jack Feldman z Uniwersytetu Ben-Guriona wraz z zespołem z Uniwersytetu Marcina Lutra w Halle i Wittenberdze prowadzi teraz fascynujące badanie porównawcze nad wieloaspektowymi doświadczeniami różnych osób zwiedzających muzeum Yad Vashem oraz Muzeum Żydowskie w Berlinie (Jüdisches Museum Berlin) indywidualnie i w grupach. Niestety, wbrew zasadom wolności prowadzenia badań, Yad Vashem ze wszystkich sił stara się ich od tego odwieść.

${ }^{10}$ Muszę też przyznać, że przepracowałem w Yad Vashem wiele szczęśliwych lat, a Instytut wspierał niektóre z moich badań. Analiza krytyczna, którą tu przedstawię, będzie do pewnego stopnia samokrytyką, ponieważ wiele z zastrzeżeń, jakie wysunę, można postawić projektowi, którym kierowałem w Yad Vashem. Było to wydanie podwójnej płyty CD o Zagładzie pod tytułem Eclipse of Humanity (Zaćmienie człowieczeństwa) w 1999 r.
} 


\section{Muzeum}

Nowe Muzeum Historyczne Yad Vashem zainaugurowało działalność w marcu 2005 r. Dwudniowa uroczystość otwarcia była jednym z najważniejszych wydarzeń dyplomatycznych i międzynarodowych w historii Izraela, ustępowała rangą jedynie pogrzebowi Icchaka Rabina. Wzięło w niej udział ponad 40 delegacji, głównie z Europy i Ameryki Północnej, przewodniczyły im głowy państw lub znane osobistości świata polityki. Wydaje się, że cały świat, a co najmniej „Zachód”, wykazując niespotykaną jednomyślność, przystał w Yad Vashem na nowy, kategoryczny imperatyw: „pamiętaj o Zagładzie”.

Samo muzeum robi ogromne wrażenie. Usytuowano je w nowym, przebudowanym kompleksie Yad Vashem o powierzchni 4200 metrów kwadratowych ${ }^{11}$, poświęconym pamięci ofiar Zagłady. Prace na projektem i budowa trwały ponad dekadę. Ekspozycje przedstawiają historię Zagłady w mniej lub bardziej chronologiczny sposób, począwszy od wydarzeń w nazistowskich Niemczech lat trzydziestych, przez prześladowania Żydów w całej Europie zakończone „ostatecznym rozwiązaniem”, po wyzwolenie i powojenną odnowę życia żydowskiego.

Wystawa kładzie ogromny nacisk na „głos jednostki” i zawiera artefakty, dzieła sztuki, oryginalne dokumenty oraz wiele relacji wideo złożonych przez ocalałych, które indywidualizują i na powrót uczłowieczają ofiary. Jak podano na stronie internetowej Yad Vashem oraz w innych oficjalnych publikacjach, muzeum przedstawia historię Zagłady z jedynej w swoim rodzaju żydowskiej perspektywy.

Co muzeum rozumie przez prezentację „,żydowskiej perspektywy historycznej” Zagłady? I dlaczego utożsamia się z nią tak wiele ludzi z całego świata?

Pierwszą salę muzeum poświęcono światu żydowskiemu w Europie przed Zagładą, który przedstawiono w wyszukanej i imponującej prezentacji multimedialnej. Oglądając następną poruszającą i przytłaczającą część wystawy, zwiedzający zapoznają się z zastosowaną w muzeum zasadą indywiduacji. Na ścianie wisi duże zdjęcie obozu w Kloodze (w Estonii) zrobione zaraz po jego wyzwoleniu przez Sowietów. Widać na nim zwłoki przygotowane do spalenia, leżące na stosie oraz między polanami. Obóz wyzwolono, zanim doszło do spalenia zwłok. Niemniej ludzkie ciało stało się tu „materiałem opałowym”. Zdjęcie jest szokujące. Stanowi ono łło ekspozycji prezentującej listy oraz artefakty, które znajdowały się w kieszeniach przyszłych ofiar, gdy te dotarły do obozu. Dzięki temu zabiegowi ofiary odzyskują człowieczeństwo. Według mnie jest to jedna z najbardziej poruszających ekspozycji w całym muzeum.

Twierdzę jednak, że jest ona przejawem głównej i nieomal jedynej zasady przyświecającej wystawie historycznej: zwiedzający ma współczuć ofierze. Ale temu k l u c z o w e m u uczuciu empatii wzbudzonemu u zwiedzających nie towarzyszy równoważące je rzeczywiste zrozumienie historii. Z tego względu narracja historyczna, a w konsekwencji odbiór muzeum, stają się zbyt „harmonijne” - wszelka

\footnotetext{
${ }^{11}$ Wszystkie dane pochodzą ze strony Yad Vashem: http://www.yadvashem.org/.
} 
„inność”, która mogłaby zdestabilizować lub zakłócić tę harmonię albo chociaż uniemożliwiłaby jej całkowite domknięcie, zostaje wyeliminowana. Kwestia ta będzie głównym wątkiem mojej analizy krytycznej.

W następnej sali jako jedynej pokazano tło historyczne, kolejne ekspozycje opowiadają już bowiem o erze nazizmu. To zadziwiające: jedna salka ma dostarczyć odwiedzającym podstawowych danych, których poznanie jest według twórców muzeum niezbędne, by móc przejść do kolejnych sal poświęconych już czasom nazizmu. Nie ma więc wątpliwości, że celowo pominięto prawie wszystkie informacje wstępne na temat sytuacji w Europie i Niemczech, z której zrodził się nazizm - zupełnie jakby uznano je za zbędne. Decyzja ta wprowadza zatem ogromną lukę już na samym początku narracji. Można odnieść wrażenie, że cała historia zaczyna się od środka.

Nie jest to do końca prawdą, skoro bądź co bądź jedna z sal dostarcza zwiedzającym pewnych informacji wstępnych. Ekspozycja ta jest jednak stosunkowo niewielka i prawie w całości koncentruje się na jednym temacie - antysemityzmie. W konsekwencji owa luka na początku narracji jest jeszcze bardziej odczuwalna, gdyż uwidacznia ona brak wzmianek o wielu innych istotnych kwestiach, takich jak modernizm, nacjonalizm, rasizm, wcześniejsze akty ludobójstwa, kolonializm i imperializm, społeczeństwo masowe, rozwój dyskursów i wykluczanie ze świata nauki, totalitaryzm, faszyzm, pierwsza wojna światowa, Republika Weimarska, współczesne państwa narodowe itd. Sam antysemityzm nie stanowi oczywiście wystarczającego tła historycznego, od razu nasuwa się bowiem pytanie: skoro nienawiść do Żydów ma tak długą historię, to dlaczego Zagłada dokonała się w połowie $\mathrm{XX}$ w.?

Antysemityzm jest niewątpliwie elementem kluczowym do zrozumienia Zagłady. Niemniej bez względu na orientację historiograficzną wszyscy historycy i inni badacze zgadzają się, że antysemityzm nie stanowi j e d y n e g o kontekstu wyjaśniającego! Kwestia głównego znaczenia antysemityzmu w porównaniu z innymi czynnikami historycznymi jest przedmiotem debat od prawie siedemdziesięciu lat ${ }^{12}$. Wydaje mi się jednak, że na początku XXI w., w obliczu wszystkiego, co odkryto, powiedziano i przedyskutowano, podanie zwiedzającym zaledwie jednego kontekstu historycznego skrajnie upraszcza, a nawet zniekształca ich wyobrażenie o Zagładzie, którą przedstawiono jako fenomen niezwiązany z historią współczesnej Europy.

Tym samym w wyjaśnieniach znajduje się luka już na początku narracji. Założę się jednak, że zdecydowana większość zwiedzających nie zaprząta sobie tym uwagi. Tak więc mimo że narracja bez wątpienia zawiera luki, mało kto je zauważa. Wydaje mi się, że oglądający po prostu się ich nie spodziewają ani nie są gotowi, by choć podejrzewać ich istnienie. Powrócę do tej kwestii później.

Od tego momentu prawie cała chronologicznie uporządkowana ekspozycja poświęcona jest erze nazizmu, tj. okresowi 1933-1945. Wystawa pokazuje eskalację

${ }^{12}$ Najbardziej aktualne i wyczerpujące streszczenie wszystkich tych debat historiograficznych zob. Dan Stone, Histories of the Holocaust, Oxford: Oxford University Press, 2010. 
i radykalizację nazistowskiej polityki antyżydowskiej, począwszy od pierwszego dekretu antysemickiego wydanego w Trzeciej Rzeszy, przez prześladowania Żydów w okupowanej Europie, utworzenie gett, masowe egzekucje przeprowadzane przez Einsatzgruppen w Związku Radzieckim oraz obozy i marsze śmierci. Owa narracja śmierci przerywana jest informacjami o przejawach życia żydowskiego i różnych formach oporu. Ważnym elementem muzeum są też liczne relacje $\mathrm{w}$ formie pisemnej i wideo.

Również w tym wypadku można dostrzec ogromne luki w narracji. Dlaczego sytuacja stale się pogarszała? Jak podejmowano decyzje dotyczące Żydów? W jaki sposób po jednej fazie następowała kolejna? Jak pokonano wszystkie przeszkody? W muzeum nie znajdziemy odpowiedzi na żadne z tych pytań. Autorzy ekspozycji nie wyjaśniają owej eskalacji, którą pokazali właściwie jako naturalne kontinuum. Zwiedzający odnoszą wrażenie, że wszechobecne zło działało zgodnie z jakąś wewnętrzną logiką pozbawioną kontekstu zewnętrznego. Szczątkowe i elementarne wzmianki o wojnie stanowią jedynie ogólne tło, a nie choćby częściowy kontekst historyczny.

Brak ów staje się nawet dotkliwszy, gdy porównamy tę narrację z inną zaprezentowaną przez Yad Vashem (jak widać, instytut uznaje więcej niż jedną). Mam tu na myśli wnikliwe badania nad „ostatecznym rozwiązaniem” przeprowadzone przez Christophera Browninga w 2004 r. Yad Vashem nie tylko je zainicjowało, lecz także opublikowało ich wyniki ${ }^{13}$. W ten sposób powstała najbardziej miarodajna praca na ten temat (przed wydaniem opus magnum Saula Friedländera). Książka ta pokazuje, jak stopniowa i „kręta”* droga prowadziła do Auschwitz oraz jak wiele pomniejszych kroków musiano zrobić i ile przeszkód - technicznych i mentalnych - trzeba było pokonać na drodze ku „ostatecznemu rozwiązaniu” (sam termin pojawił się w dokumentach nazistowskich już w 1940 r., odnoszono go wtedy raczej do innych „rozwiązań” niż do totalnej eksterminacji Żydów ${ }^{14}$ ).

Mógłbym mnożyć przykłady, przywołując chociażby mylącą prezentację słynnego przemówienia Hitlera ze stycznia 1939 r. ${ }^{15}$, brak wzmianek o planie deportacji

${ }^{13}$ Christopher R. Browning, The Origins of the Final Solution: The Evolution of Nazi Jewish Policy, Lincoln-Jerusalem: Nebraska University Press i Yad Vashem, 2004.

* Goldberg nawiązuje tu do książki Karla A. Schleunesa, Twisted Road to Auschwitz. Nazi Policy toward German Jews, 1933-1939, wyd. 2 rozsz., Urbana: University of Illinois Press, 1990 (przyp. red.).

${ }^{14}$ Zob. na przykład Götz Aly, Final Solution, London: Arnold Press, 1999, s. 3; Philippe Burrin, Hitler and the Jews, London: Arnold Press, 1994, s. 88.

${ }^{15}$ Zob. na przykład Ian Kershaw, Hitler's Prophecy and the „Final Solution” [w:] On Germans and Jews under the Nazi Regime, red. Moshe Zimmermann, Jerusalem: the Hebrew University Magnes Press, 2006, s. 49-66. W eseju uznano owe przemówienie za kamień milowy na drodze ku „ostatecznemu rozwiązaniu”. Niemniej w przeciwieństwie do muzeum autor przedstawia wszystkie jego zawiłości i nie traktuje go jako definitywnej decyzji i ostatecznego planu. Znacznie bardziej radykalna, „funkcjonalistyczna” analiza tego przemówienia zob. Hans Mommsen, Hitler's Reichstag speech of 30 January 1939, „History and Memory” 1997, t. 9 , nr $1-2$, s. $147-161$. 
na Madagaskar itp. Zatrzymam się tylko na jednym. Zdaniem Browninga, który podsumowuje ustalenia historyków „ostatecznego rozwiązania”, masowe mordy na Żydach w ZSRR w lecie, a zwłaszcza do sierpnia 1941 r., nie stanowiły jeszcze jego części (jak napisano na jednym z paneli w muzeum), lecz element nazistowskiej polityki terroru polegającej na „uspokojeniu okupowanych terytoriów”, zwalczaniu partyzantów oraz eksterminowaniu elity bolszewickiej. Był to ostatni etap w przygotowywaniu gruntu pod totalne wyniszczenie Żydów na okupowanych terenach Związku Radzieckiego, przeprowadzone kilka tygodni później. Etap ten nastąpił jeszcze przed podjęciem decyzji o rozszerzeniu tej polityki na całą Europę. W rzeczywistości, jak ostatnio stwierdził Ian Kershaw ${ }^{16}$, użycie słowa „decyzja” w tym kontekście może wprowadzać w błąd: „mówienie w tym wypadku o «decyzji» może już samo w sobie być mylące, sugeruje to bowiem jakiś jeden skończony moment, w którym zostało wydane precyzyjne oświadczenie. Zastanawiając się, jak się to dokonało, prawdopodobnie należałoby przyjąć raczej serię upoważnień, przy czym każde z nich opierało się na poprzednich”. Dalej w tym samym rozdziale Kershaw dodaje: „Nie następowały one po sobie [etapy prowadzące do ludobójstwa - A.G.] w wyniku wyraźnych rozkazów przekazywanych z wierzchołka piramidy do jej podstaw. Było to raczej skomplikowane wzajemne powiązanie wysyłanych z góry sygnałów o «zielonym świetle» dla działania z inicjatywami podejmowanymi oddolnie, których połączenie wytwarzało spiralę radykalizacji”"17.

Muzeum w żaden sposób nie porusza tych ani wielu innych zawiłości historycznych ${ }^{18}$. Tak samo nie pokazuje ono ani nawet nie wspomina o tragedii prawie $3 \mathrm{mln}$ żołnierzy sowieckich, którzy zostali zabici lub umarli z głodu w ciągu zaledwie roku (co daje około 7 tys. ofiar dziennie).

Nie uważam bynajmniej, że muzeum jest lub powinno spełniać wymogi historycznej publikacji akademickiej. Niemniej nie powinno ono, a nawet nie może uchylać się od zmierzenia się z pewnymi zawiłościami tego niezwykle złożonego wydarzenia. Zaryzykowałbym nawet stwierdzenie, że w wypadku Zagłady wiąże się z tym nie tylko odpowiedzialność historyczna, lecz także bardzo poważna odpowiedzialność moralna.

Co więcej, w muzeum brakuje konfrontacji z kwestią sprawców (lub świadków) i którąkolwiek z palących kwestii historycznych, psychologicznych, społecznych, filozoficznych czy etycznych, które na nich oddziaływały. Całkowicie pominięto

${ }^{16} \mathrm{Z}$ rozmysłem odwołuję się tutaj do Kershawa, który w swojej ostatnio wydanej książce opowiada się po stronie „intencjonalistów” w podejściu do „ostatecznego rozwiązania” i który w związku z tym zebrał pochwały izraelskiego historyka Israela Gutmana. Zob. jego recenzja w „Haaretz Literary Supplement”, 22 IV 2009 (w języku hebrajskim).

${ }^{17}$ Ian Kershaw, Punkty zwrotne. Decyzje, które zmienity bieg drugiej wojny światowej, tłum. Michał Romanek, Kraków: Znak, 2009, s. 610-611, 632.

${ }^{18}$ Niektóre $z$ tych kwestii poruszane są w ośrodku edukacyjnym, oddzielonym od muzeum historycznego i odwiedzanym przez bardzo niewiele grup, głównie szkolnych. 
głównych uczestników tego wydarzenia historycznego, tj. sprawców ${ }^{19}$. Brak ów nie powoduje jedynie zniekształcenia przedstawianych wydarzeń - według mnie mamy tu do czynienia z ich antyprzedstawieniem, w konsekwencji muzeum prezentuje bowiem czyny bez sprawców. Zagłada wyniesiona zostaje na poziom mitu, gdyż muzeum przedstawia ją w oderwaniu od jej ziemskich „przyczyn i skutków” oraz od rozumowania i wyjaśniania. Wydarzenia prezentuje się jako „pewnik”, ujawniający jakąś odwieczną prawdę o świecie, a właśnie to jest cechą charakterystyczną mitu. Zagładzie przedstawionej w taki sposób, jak to zrobiono w muzeum, brakuje ziemskiego wymiaru.

Jest to uderzające. Wszak zarówno narrator muzeum, jak i potencjalny, niezorientowany adresat wychodzą z założenia, że Zagłada była wydarzeniem bezprecedensowym, wydarzeniem intuicyjnie wymykającym się możliwości zrozumienia. Była wielkim i katastrofalnym w skutkach historycznym znakiem zapytania! To właśnie z tego powodu buduje się, odwiedza i poważa muzeum upamiętniające tamto wydarzenie. Przyjąwszy taki punkt wyjścia, pragnie się wyjaśnienia, wypełnienia pustej przestrzeni „niedowierzania”20: jak do tego doszło? Co zaskakujące, muzeum całkowicie unika tego pytania. Odnoszę jednak wrażenie, że ani ono nie stara się uzupełnić luk, ani większość odwiedzających w ogóle nie zdaje sobie z nich sprawy. Prawdopodobnie nie oczekują oni żadnych wyjaśnień, a nawet nie są na nie przygotowani. Jak stwierdziłem na początku: muzeum wzbudza współczucie dla ofiar, ale zawiesza rozumienie historii.

\section{Empatia i władza}

Architektura muzeum z pewnością przyczynia się do owego braku wyjaśnień. Placówka znajduje się na terenie rozległego kompleksu poświęconego pamięci ofiar Zagłady, którego projekt architektoniczny miał zapewne jedynie epatować ogromem. Wszystko jest olbrzymie, jak w przypadku autorytarnej architektury, mającej

${ }^{19}$ Zaskakujące jest to, że na hebrajski przetłumaczono zaledwie znikomy ułamek bogatej literatury historycznej poświęconej sprawcom (mam tu na myśli monografie; artykuły publikowano w różnych czasopismach, łącznie z „Yad Vashem Studies” i „Dapim”). Na hebrajski nie przetłumaczono nawet książki Raula Hilberga z 1961 r. The Destruction of the European Jews. Yad Vashem odmówiło jej wydania w latach sześćdziesiątych. Dopiero teraz tłumaczona jest tam na hebrajski. Trzeba jednak wspomnieć również, że spośród nielicznych książek przetłumaczonych w ciągu ostatnich kilku lat Yad Vashem wydało kilka bardzo ważnych pozycji: Browning, The Origins of the Final Solution...; Ulrich Herbert, Nazionalsozialistische Vernichtungspolitik (przekład ukazał się w 2001 r.). Zob. też Amos Goldberg, One out of Four: On What Jaeckel, Hilberg and Goldhagen Have in Common and What is Unique about Christopher Browning, „Yalkut Moresht”, zima 2006. Dokładniejsze omówienie izraelskiej historiografii Zagłady zob. Dan Michman, Holocaust Historiography: A Jewish Perspective: Conceptualizations, Terminology, Approaches, and Fundamental Issues, London-Portland: Vallentine Mitchell, 2003.

${ }^{20}$ Saul Friedländer, Czas eksterminacji. Nazistowskie Niemcy i Żydzi 1939-1945, Warszawa: Prószyński i S-ka, 2010, s. 29. 
skłonić jednostkę do podporządkowania się władzy wyższej. Zwiedzających wita wielki łuk, za którym rozciąga się rozległy, wręcz imperialny dziedziniec. Położone nieopodal „centrum dla zwiedzających”, czyli wejście do kompleksu muzealnego, przypomina grecką świątynię z masywnego, surowego betonu. Co za przytłaczający widok!

Jeśli już o tym mowa, chciałbym nadmienić, że w muzeum znajduje się tylko jedna kręta trasa zwiedzania. Odwiedzający nie mogą przerwać wizyty w muzeum ani ominąć którejkolwiek z sal. Sama ekspozycja jest przeładowana zdjęciami, filmami wideo, artefaktami i panelami wyjaśniającymi, że muzeum „stawia sobie za cel uchwycenie całokształtu Zagłady, stworzenie ostatecznej, całościowej interpretacji Katastrofy”, by zacytować trafną krytykę waszyngtońskiego Muzeum Pamięci Holokaustu autorstwa Kseni Polouektovej ${ }^{21}$.

Gmach muzeum „przypomina leżący graniastosłup o trójkątnej podstawie. Przecina on wierzchołek góry, tak że oba jego końce wystają ze zbocza, co daje bardzo dramatyczny efekt”22. Zwiedzający wchodzą do muzeum po moście, a wizytę kończą na krawędzi przepaści. Wkraczając do środka, zostajemy dosłownie odcięci od zewnętrznego świata codzienności. W muzeum działa logika inna niż na zewnątrz. Zwiedzający przechodzą po moście i schodzą pod ziemię, gdzie nikt nie zastanawia się nad lukami w narracji, które tracą swój niepokojący charakter. To właśnie tam odwiedzający mają stawić czoło Zagładzie.

Można odnieść wrażenie, że pakt pomiędzy autorem narracji muzealnej a jej odbiorcą (zwiedzającym) bazuje na autorytatywnym, niczego niewyjaśniającym opisie. U jego podstaw leży obustronne pragnienie niezrozumienia. Potencjalny odwiedzający nie oczekuje, ani też nie oczekuje się po nim, uzyskania informacji o przyczynach i przebiegu wydarzeń, co pozwoliłoby w miarę możliwości zapełnić owe luki. Ten „pakt” nie pozwoli mu nawet przeczuć jakiejkolwiek ambiwalencji. Wydaje się, że owe przerażające wydarzenia nadeszły znikąd. Innymi słowy, do muzeum nie przychodzi się, by choćby częściowo zrozumieć wydarzenia, lecz by doświadczyć czegoś innego. To „coś innego” pozbawione jest przyziemnego sensu i za pomocą omówionych już środków zostaje wyniesione do poziomu uświęconego i autorytatywnego mitu. Jakiej jest natury?

Na stronie internetowej muzeum można przeczytać, że celem instytucji jest „prezentowanie historii Zagłady z wyjątkowej, żydowskiej perspektywy, podkreślanie doświadczeń jednostek przez wykorzystanie oryginalnych wytworów, relacji ocalonych oraz rzeczy osobistych"23. Oznacza to, że głównym zadaniem muzeum jest prowadzenie narracji historycznej, tak by oddać głos ofiarom, lub, dokładniej mówiąc, ofiarom żydowskim, ponieważ to one są najważniejszymi

${ }^{21}$ Ksenia Polouektova, Holocaust, Representation, Memory: Notes on the USHMM, Washington, D.C., „Jewish Studies at the CEU” 2005-2007, nr 5, s. 128.

${ }^{22}$ http://www1.yadvashem.org/yv/en/museum/architecture.asp?CSRT=1434878364311 078672, dostęp 17 X $2011 \mathrm{r}$.

${ }^{23}$ Ibidem. 
i zarazem jedynymi bohaterami tej narracji. Wysłuchanie świadectwa ofiary oraz odczuwanie empatii w stosunku do jej historii jest oczywiście głównym imperatywem etycznym ${ }^{24}$.

„Głosy jednostek” prawie nigdy jednak nie kwestionują w swojej jednostkowości autorytatywnej narracji historycznej. W większości zostały one starannie dobrane w celu potwierdzenia, zilustrowania i rozwinięcia prezentowanej w muzeum opowieści. Bardzo rzadko ją kwestionują, podważają lub choćby ujawniają pewną ambiwalencję, jak to zwykle bywa w wypadku „głosów jednostek”. Wydaje mi się, że głosy te zostały prawie całkowicie podporządkowane ogólnej, bardzo sztywnej narracji historycznej. Nie są one dialogiczne w bachtinowskim znaczeniu tego terminu ${ }^{25}$, a zatem tracą swój jednostkowy charakter.

Nie jest to jednak jedyny problem, jaki tu dostrzegam. Skoro dawanie świadectwa w ten czy inny sposób oznacza identyfikację z ofiarą przy jednoczesnym całkowitym zrezygnowaniu z konfrontacji z pokrętną logiką działań nazistów (jakby jedno musiało pociągać za sobą drugie), to z psychoanalitycznego punktu widzenia znajdujemy się raczej w sferze wyobraźni niż symboli - w sferze melancholii, a nie żałoby.

Mówiąc o melancholii, mam na myśli definicję Erica Santnera ${ }^{26}$, sformułowaną po ukazaniu się słynnego eseju Zygmunta Freuda Żałoba a melancholia ${ }^{27}$ z 1917 r. Owa melancholijna pamięć opiera się na narcystycznych procesach identyfikacji z ofiarą, w których dąży ona do usunięcia z narracji wszelkiej zakłócającej je „inności”28. Owa „narracja żydowska” stanowi całość samą w sobie i jest niedostępna dla jakiejkolwiek „inności” ujętej historycznie, w wyniku czego staje się, jak twierdzę, narracją mityczną. Jak już pokazałem, niemal zupełnie wyklucza ona ze swojego obrębu wszelką inność nieżydowską. Brakuje nieżydowskiego tła historycznego, informacji o wcześniejszych aktach ludobójstwa czy masowych mordach. Nie ma wzmianek o rasizmie, koloniach czy sprawcach. Niemal całkowicie pominięto również kwestię świadków. Co więcej, nie ma prawie żadnych informacji o nieżydowskich ofiarach Zagłady ${ }^{29}$.

\footnotetext{
${ }^{24}$ Carolyn J. Dean, The Fragility of Empathy after the Holocaust, Ithaca: Cornell University Press, 2004.

${ }^{25}$ Mikhail Bakhtin, The Dialogical Imagination: Four Essays, Austin: University of Texas Press, 1982 [zob. też Michaił Bachtin, Dialog, język, literatura, red. Eugeniusz Czaplejewicz, Edward Kasperski, Warszawa: Państwowe Wydawnictwo Naukowe, 1983 - przyp. red.].

${ }^{26}$ Eric L. Santner, Stranded Objects: Mourning, Memory, and Film in Postwar Germany, Ithaca: Cornell University Press, 1990.

${ }^{27}$ Zygmunt Freud, Żałoba a melancholia, tłum. Barbara Kocowska [w:] Kazimierz Pospieszyl, Zygmunt Freud. Człowiek i dzieło. Wrocław: Ossolineum, 1991, s. 295-308.

${ }^{28}$ Przez „inność” rozumiem tu jakikolwiek element, który nie mógłby być łatwo włączony do danego planu czy układu konceptualnego lub epistemologicznego.

${ }^{29}$ Ten temat omówiono dość szczegółowo na początku trasy zwiedzania, w sali poświęconej Niemcom nazistowskim. Znajdują się tam panele opowiadające o Sintich i Romach, ofiarach eutanazji i przeciwnikach politycznych nazistów. O Sintich i Romach traktuje również panel schowany przy wejściu do części wystawy dotyczącej obozów.
} 
Choć to bardzo narcystyczne i problematyczne, łatwo zrozumieć, dlaczego grupa ofiar tak straszliwej tragedii historycznej jak Zagłada identyfikuje się z taką narracją i rezygnuje z prób włączenia do niej innych perspektyw, choćby na bardzo ograniczoną skalę. Wydaje się jednak, że owa tendencja, by doświadczać pamięci o Zagładzie przez wyłączną i całkowitą „identyfikację z ofiarą (żydowską)”, to znacznie powszechniejsze zjawisko kulturowe, które zdominowało wiele najważniejszych przedstawień Zagłady, na przykład berlińską wystawę poświęconą pamięci ofiar, niedawno otwartą na terenie dawnego obozu Bergen-Belsen, a nawet dwutomowe błyskotliwe opus magnum Saula Friedländera o historii Holokaustu ${ }^{30}$. Wszystkie te przedstawienia obficie czerpią z „głosów ofiar” jako centralnej epistemologicznej perspektywy historii Zagłady i pamięci o niej. Wszystkie one w pewnym sensie „manipulują” swoimi odbiorcami, tak by ci przede wszystkim, a czasami nawet wyłącznie, silnie identyfikowali się z ofiarami.

Pojawia się pytanie: dlaczego? Dlaczego nieżydowscy mieszkańcy Zachodu również utożsamiają się silnie z narracją, kładącą tak wielki nacisk na odczuwanie empatii w stosunku do ofiar żydowskich oraz na identyfikację z nimi?

Odpowiedź jest bez wątpienia bardzo skomplikowana i wiąże się, przynajmniej częściowo, ze znacznie bardziej ogólnymi trendami kulturowymi. Łączy się to ściśle na przykład z „erą świadka” - jak trafnie nazwała nasze czasy francuska historyczka Annette Wieviorka ${ }^{31}$ - w której to ofiary i naoczni świadkowie przybliżaja ogółowi społeczeństwa każde historyczne lub warte wzmianki w mediach wydarzenie. Według mnie wiąże się to też ściśle z czymś, co Eva Illouz nazywa pojawieniem się homo sentimentalis w kulturze, która przyjęła głównie terapeutyczną narrację własnego ja. Według niej jest to jedna z najbardziej rozpowszechnionych cech współczesnej kultury Zachodu ${ }^{32}$.

${ }^{30}$ Zostało ono entuzjastycznie przyjęte właśnie dlatego, że Saulowi Friedländerowi udało się włączyć do wyczerpującej narracji głosy ofiar. Zob. idem, Nazi Germany and the Jews 1933-1939: The Years of Persecution, New York: Harper Collins, 1997; idem, The Years of Extermination... Gruntowna teoretyczna, historiograficzna i krytyczna analiza książki zob. Wulf Kansteiner, Success, Truth, and Modernism in Holocaust Historiography: Reading Saul Friedländer Thirty-Five Years after the Publication of Metahistory, „History and Theory” 2009, nr 47, s. 25-53, oraz forum opublikowane w „History and Theory” 2009, t. 48, nr 3, zawierające odpowiedzi Alona Confino, Narrative Form and Historical Sensation: On Saul Friedländer's The Years of Extermination, s. 199-219, Amosa Goldberga, The Victim's Voice and Melodramatic Aesthetics in History, s. 220-237, i Christophera Browninga, Evocation, Analysis, and the „Crisis of Liberalism”, s. 238-247. Zob. też Dominick LaCapra, Historical and Literary Approaches to the „Final Solution”: Saul Friedländer and Jonathan Littell, „History and Theory”, luty 2011, t. 50, nr 1, s. 71-97; Dan Stone, Constructing the Holocaust: A Study in Historiography, London: Vallentine Mitchell, 2003, s. 161-164; Carolyn J. Dean, Minimalism and Victim Testimony, „History and Theory”, grudzień 2010, t. 49 , s. 85-99.

${ }^{31}$ Annette Wieviorka, The Era of the Witness, Ithaca: Cornell University Press, 2006.

${ }^{32}$ Eva Illouz, Cold Intimacies: The Making of Emotional Capitalism, Cambridge: Polity Press, 2007. 
W tym krótkim eseju nie jestem w stanie udzielić ostatecznej odpowiedzi, ale z pewnością mogę snuć domysły. Sugerowałbym więc, by odpowiedzi, przynajmniej częściowej, szukać na poziomie politycznym, skoro, jak wcześniej wspomniałem, otwarcie muzeum Yad Vashem stało się wydarzeniem bardziej politycznym niż kulturalnym czy edukacyjnym. Chciałbym pokrótce przeanalizować mowę wygłoszoną przez Cemila Çiçka, tureckiego ministra sprawiedliwości, jeszcze przed obecnym kryzysem w stosunkach między Izraelem a Turcją. Uważam, że może to wiele wyjaśnić. Nie podejrzewalibyśmy Turcji o przywiązanie do takiego dyskursu o Zagładzie i taką formę pamięci o niej. Holokaust nie ma nic wspólnego z Turcją, a jednak ów kraj pukający wówczas do drzwi Europy, zrobił wszystko, by przyswoić europejski dyskurs polityczno-etyczny. Oto słowa ministra:

Yad Vashem to nie tylko miejsce żałoby. To też miejsce człowieczeństwa. Musimy dziś w pewnym celu przywołać lekcje płynące $z$ historii. A celem tym jest przekazanie ich przyszłym pokoleniom. I wszyscy co do jednego musimy zrozumieć, że nie możemy dopuścić, by kiedyś doszło do jakichkolwiek aktów ludobójstwa. Musimy wyciągnąć naukę z Zagłady: nie możemy pozwolić, by gardzono jakąkolwiek religią czy ludem bądź je demonizowano. Ludobójcze czystki etniczne, rasizm, antysemityzm, paniczny lęk przed islamem czy chrześcijaństwem, ksenofobia - wszystkie te przejawy zła o długiej historii nadal stanowią zagrożenie. Wszyscy czujemy się w obowiązku je pokonaćs ${ }^{33}$.

Można zapytać: dlaczego na uroczystość zaproszono przedstawicieli Turcji, która sama, choć temu zaprzecza, dopuściła się ludobójstwa, podczas gdy zabrakło na niej przedstawicieli Romów i Sintich oraz takich krajów, jak Armenia, Rwanda czy Kambodża, których obywatele również padli ofiarami ludobójstwa? Oni nie zostali zaproszeni, nie mogli więc zabrać głosu w trakcie inauguracji. Nie o to jednak chcę zapytać. Pragnę zadać następujące pytanie: co takiego ma w sobie struktura i funkcja dyskursu Yad Vashem o Zagładzie, że Turcja, chcąc, by uznano ją za członka cywilizowanego świata, nie tylko może, ale jest wręcz zobowiązana w nim uczestniczyć?

Jest oczywiste, że mamy tu do czynienia z podwójnym dyskursem. Reakcja na zagładę Żydów jest dla Turcji sposobem na zapomnienie o innym akcie ludobójstwa, w którym sama brała udział. Oto w Yad Vashem przedstawiciele Stambułu potępiają Zagładę i wszelkie akty ludobójstwa, przeciwstawiają się wszelkim przejawom nienawiści, przez co udowadniają swoją przynależność do rodziny narodów cywilizowanych. W pewnym sensie gotowi są opłakiwać ofiary żydowskie, unikając czy wręcz po to, ż e b y uniknąć konieczności opłakiwania zabitych Ormian i wzięcia jakiejkolwiek odpowiedzialności za ich eksterminację. Turcja woli identyfikować się z „Żydem”, który był wtedy dla niej wyobrażonym innym, i uniknąć konfrontacji z tym prawdziwym, czyli z Ormianami. Podczas uroczystości w Yad Vashem Turcy mogli podtrzymać liberalny dyskurs humanistyczny przez dawanie

${ }^{33}$ http://www1.yadvashem.org/yv/en/about/events/pdf/museum_opening/turkey.pdf? CSRT=1434878364311078672, dostęp 17 X $2011 \mathrm{r}$. 
świadectwa Żydom, przy jednoczesnym niemal cynicznym unikaniu tematu swojego uczestnictwa w ludobójstwie, pozostającym w sprzeczności z tym właśnie dyskursem.

Pod tym względem jest to „pamięć zastępcza” (screen memory) w psychoanalitycznym znaczeniu tego terminu ${ }^{34}$ - Turcy pamiętają o jednym, by zapomnieć o drugim. Czy jest to symptom jakiejś ogólniejszej tendencji?

\section{Narracja krzepiąca?}

Historyk Charles Maier wykazał ${ }^{35}$, że dwie wielkie narracje, które zdominowały zachodnie rozumienie nowoczesności, lokują w swoim centrum katastrofę. Pierwsza z nich to „narracja demokratyczna”, odnosząca się przede wszystkim do Holokaustu. Zagłada postrzegana jest w niej jako efekt działań barbarzyńskich sił, które usiłowały zatrzymać Zachód na teleologicznie pojmowanej drodze ku nowoczesności, tzn. ku bardziej liberalnej i demokratycznej egzystencji. To „ci źli” - naziści - wszystko zepsuli i jeśli tylko nie zrezygnujemy z naszych wartości demokratycznych i wzmocnimy nasze społeczeństwo obywatelskie przy jednoczesnym łagodzeniu ideologicznie radykalnych trendów, to nie popadniemy w zbrodniczość i tym samym wzmocnimy naszą reputację jako „tych dobrych” - obrońców demokracji i wolności. Paradoksalnie jest to więc narracja krzepiąca.

Druga narracja ma związek z inną katastrofą - kolonialnym i postkolonialnym doświadczeniem Zachodu. Według niej kolonializm stanowi przykład immanentnej „mrocznej i zbrodniczej strony” naszej współczesnej cywilizacji Zachodu. Narracja postkolonialna krytykowała zachodnie społeczeństwa i ich systemy demokracji liberalnej za ich stałe bezpośrednie i strukturalne zaangażowanie w akty dominacji, rasizm, skrajną przemoc i zbrodniczość.

Ogólnie rzecz biorąc, w latach pięćdziesiątych i na początku lat sześćdziesiątych te dwie narracje służyły niektórym intelektualistom za narracje polityczne i były ze sobą ściśle związane. Widać to wyraźnie w tekstach Franza Fanona, Hannah Arendt, Alaina Renais'a, Jeana-Paula Sartre’a, Charlotte Delbo i wielu innych ${ }^{36}$. Ale prawda jest taka, że przez ostatnie kilkadziesiąt lat te dwie narracje - krytyczna narracja postkolonialna i narracja postholokaustowa, lamentująca, a zarazem w pewnym sensie krzepiąca - prawie w ogóle się ze sobą nie zbiegają, a jeśli już, to rzadko.

Sugerowałbym, że być może tak przekonująco zaprezentowany w Yad Vashem imperatyw, by identyfikować się z ofiarami, odgrywa rolę w przekształceniu Zagłady w narrację krzepiącą, która maskuje mroczną stronę nowoczesności i Zachodu. Zamiast uhistoryczniać i kontekstualizować te traumatyczne wydarzenia oraz

\footnotetext{
${ }^{34}$ Sigmund Freud, Screen Memories, The Standard Edition of the Complete Psychological Works of Sigmund Freud, t. 3: Early Psycho-Analytic Publications (1893-1899), s. 299-322.

${ }^{35}$ Charles S. Maier, Consigning the Twentieth Century to History: Alternative Narratives for the Modern Era, „American Historical Review”, czerwiec 2000, t. 165, nr 3, s. 807-831.

${ }^{36}$ Michael Rothberg, Multidirectional Memory: Remembering the Holocaust in the Age of De-Colonization, Stanford: Stanford University Press, 2009.
} 
przeanalizować tamte katastrofalne elementy historii współczesnej i ogólnie nowoczesności, które doprowadziły do Zagłady, ta narracja krzepiąca ucieka w zwykłe melancholijne i niby-wzniosłe katharsis, osiągane przez identyfikację ze straszliwym losem dawnych ofiar. Zaryzykowałbym nawet stwierdzenie, że utożsamianie się z ofiarą żydowską jest tak łatwe, bo w Europie prawie nie ma Żydów, a oni sami - jako grupa, a często też jako jednostki - nie są już ofiarami historii, lecz raczej jej potężnymi aktorami. Być może ta „niezasłużona identyfikacja” (unearned identification), by użyć terminu Dominicka LaCapry ${ }^{37}$, zagłusza lub minimalizuje empatię w stosunku do ofiar cierpiących obecnie - empatię, która wymaga moralnej i politycznej siły oraz znacznie odważniejszego i bardziej złożonego zaangażowania na świecie ${ }^{38}$.

Jeśli moja hipoteza jest słuszna, to można zaobserwować tu zwykłą zbieżność pomiędzy narracją ofiar a narracją zachodnią. Z bardzo różnych powodów obie zmierzają do takiego włączenia Zagłady w dyskurs żydowski, w którym nadaje się nadmierne znaczenie antysemityzmowi w stosunku do rasizmu czy jakiegokolwiek innego kontekstu historycznego (o czym już wspominałem) i koncentruje się na ofiarach żydowskich, pomijając przy tym inne grupy ofiar nazizmu lub innych ideologii europejskich. Trzeba jednak zachować tu dużą dozę ostrożności, pamiętając o ostrzeżeniu sformułowanym przez Dominicka LaCaprę: „Działa tu mechanizm polegający na czynieniu z Żydów niejako kozła ofiarnego: dawna ofiara staje się postacią niosącą zbawienie współczesnemu światu, z którą się identyfikujemy”39.

I prawdę mówiąc, wyraźnie widać działanie owego mechanizmu już w samym muzeum: wyklucza ono wszelką „inność” z tego, co przyjmuje za „narrację żydowską”. W efekcie owa logika wykluczania ofiarniczego zostaje w nim niechcący powielona. Znacznie ogranicza się lub wręcz całkowicie pomija każdą inność historyczną, kolidującą z zamkniętą i stanowiącą zamkniętą całość (żeby nie powiedzieć narcystyczną, a nawet szowinistyczna) narracją. W efekcie otrzymujemy mityczną narrację ofiar, do której historia nie ma dostępu i która jedynie zachęca do identyfikacji czy nawet jej wymaga.

${ }^{37}$ Dominick LaCapra o „niezasłużonym pokrzepieniu duchowym” (unearned spiritual uplifting) i „niezasłużonym rozsądku” (unearned judiciousness) w przedstawianiu traumy zob. Writing History, Writing Trauma, Baltimore: Johns Hopkins University Press, 2001, rozdz. 1.

${ }^{38}$ Zgadzam się tu z Peterem Novickiem i innymi, którzy nie dostrzegają w pamiętaniu o Zagładzie prawdziwego oddania wartościom, takim jak prawa człowieka i wolność. Zob. Peter Novick, The Holocaust in American Life, Boston-New York, 1999, s. 239-262. W kontekście polityki żydowskiej i izraelskiej można by się pokusić o odwrotne stwierdzenie. Zob. na przykład Sidra DeKoven Ezrahi, „To Write Poetry after Auschwitz You Need the Barbarians” (tytuł wstępny) mające się ukazać w: After Testimony, red. Jakob Lothe, Jim Phelan, Susan Suleiman, Columbus: Ohio State University Press (w przygotowaniu); oraz Idith Zertal, Israel's Holocaust and the Politics of Nationhood, Cambridge: Cambridge University Press, 2005. Bardzo problematyczna (delikatnie mówiąc) książka, która zawiera jednak ziarno prawdy, to Norman Finkelstein, Przedsiębiorstwo holokaust, tłum. Mateusz Szymański, Warszawa: Volumen, 2001.

${ }^{39}$ LaCapra, Writing History..., s. 123. 
Jest to szczególnie widoczne na końcu trasy zwiedzania. Zwiedzający wychodzą na piękny balkon zawieszony na krawędzi przepaści, z którego rozciąga się cudowny widok na żydowskie wioski i pokryte kwieciem wzgórza. Ów budujący, piękny i syjonistyczny w wymowie widok czyni zadość całej historii, a gość po osiągnięciu tego punktu katharsis może odetchnąć z ulgą: dzięki Bogu, ten metafizyczny dramat zakończył się szczęśliwe. Zostaje on pocieszony w sposób bardzo podobny do tego, co Saul Friedländer nazywa krzepiącym połączeniem kiczu i śmierci, czyli w myśl jego definicji, uderzającym zestawieniem niesamowitych potworności z sielskimi, uspokajającymi obrazami ${ }^{40}$. Ogromny szok wywołany przez pozbawioną w dużej mierze kontekstu wystawę zostaje zamieniony w dodające otuchy doświadczenie, pozbawione jakichkolwiek niepokojących historyczno-politycznych czy etycznych kwestii istotnych dla teraźniejszego prawdziwego życia.

Niektórzy teoretycy nadali takiemu zjawisku miano „narracji odkupiającej” (redemptive narrative) - jej celem jest zadośćuczynienie całej traumatycznej i katastrofalnej inności tej opowieści przez niemal całkowite stłumienie jej pozornie szczęśliwym i krzepiącym zakończeniem. Owi teoretycy obszernie omawiają niebezpieczeństwa polityczne i etyczne, jakie niosą ze sobą takie narracje ${ }^{41}$. Nie będę przytaczał tutaj tej dyskusji, powiem tylko, że takie narracje odkupiające są tak krzepiące (często w melancholijny, a nawet melodramatyczny sposób) i niosą ze sobą taki ładunek emocjonalny dla grup narodowych, które przyjmują je jako swoją narrację polityczną (właśnie dlatego, że są odkupiające), że często są one skrajnie autorytatywne i nie podlegają dyskusji. W czasach konfliktów politycznych moga się okazać bardzo niebezpieczne ${ }^{42}$.

Zatoczyliśmy koło, śledząc wykluczanie wszelkiej inności z „historycznej” narracji muzeum - brak w niej kontekstu (zaprezentowano tylko szczątkowe tło historyczne na temat drugiej wojny światowej), genezy historycznej (z wyjątkiem antysemityzmu), prawdziwych sprawców, prawdziwych ofiar przeżywających traumę, omówienia życia powojennej diaspory i tematu ofiar nieżydowskich. Zaserwowano nam mityczny dramat zaczynający się antysemityzmem, po którym następuje wielka katastrofa i któremu zadość czyni powojenny klimat syjonizmu pozbawionego wymiaru materialnego i zyskującego symboliczne, a być może nawet metafizyczne znaczenie.

${ }^{40}$ Saul Friedländer, Reflections of Nazism: An Essay on Kitsch and Death, New York: Harper and Row, 1984.

${ }^{41}$ Zob. na przykład LaCapra, Writing History...; Loss: The Politics of Mourning, red. David L. Eng, David Kazanjian, Berkeley: University of California Press, 2003.

${ }^{42}$ W tej kwestii warto wspomnieć, że w 2009 r. przewodnik oprowadzający uczniów, Itamar Shapira, który w trakcie rozmowy ze studentami ośmielił się wspomnieć o Nubie - palestyńskim Dniu Katastrofy, został natychmiast zwolniony z Yad Vashem. Powiedział, że Palestyńczycy też doświadczyli traumy, która ukształtowała ich świadomość narodową. Zob. http://www.haaretz.com/print-edition/news/yad-vashem-fires-employee-who-comparedholocaust-to-nakba-1.274624, dostęp 17 X $2011 \mathrm{r}$. 
Chciałbym podkreślić, że moja krytyka nie jest wymierzona w owo syjonistyczne w wymowie zakończenie trasy zwiedzania muzeum, lecz - jak w nieco innym kontekście ujął to izraelski filozof Adi Ophir - w źle pojętą świętość takiego krzepiącego, być może nawet wzniosłego doświadczenia, w którym łączą się człowiek, historia i natura, tworząc wyobrażoną stabilną tożsamość, przy jednoczesnym tłumieniu i wykluczaniu z niej wszelkiej inności - zarówno od wewnątrz, jak i od zewnątrz ${ }^{43}$.

To zjawisko uderza mnie jako najbardziej problematyczne w muzeum Zagłady. Jeśli bowiem istnieje jakaś kwestia etyczna, która stała się niesłychanie pilna po Zagładzie, to jest nią właśnie kwestia „innego” i świadomości naszych mechanizmów kulturowo-politycznych i psychologicznych, za pomocą których obchodzimy i tłumimy tę kwestię czy jej unikamy, co koniec końców prowadzi do ekstremalnej przemocy.

Z języka angielskiego przełożyła Anna Brzostowska

\title{
Słowa kluczowe
}

Muzeum Yad Vashem, narracje o Zagładzie, „Inny”

\begin{abstract}
The essay analyzes the main exhibition of Yad Vashem New Holocaust Museum (opened in 2005) as a historical narrative, with particular criticism directed at the forms of narration used. According to the author, the main problem is that the museum's narration excludes all otherness - it lacks context (only fragmentary historical background of World War II was presented), historical genesis (with the exception of anti-Semitism), real perpetrators, real victims experiencing trauma, discussion of the life of the post-war Diaspora and the topic of non-Jewish victims.
\end{abstract}

\section{Key words}

Yad Vashem Museum, Holocaust narrations, the "Other"

${ }^{43}$ Adi Ophir, Awodat ha-Howe [Praca doby obecnej], Tel Aviv: Hakibbutz Hameuchad, 2001. 